SELECTED U.S. GEOLOGICAL SURVEY PUBLICATIONS ON THE

WATER RESOURCES OF VIRGINIA, 1910-91

Compiled by Judith A. McFarland

U.S. GEOLOGICAL SURVEY

Open-File Report 92-69

Richmond, Virginia

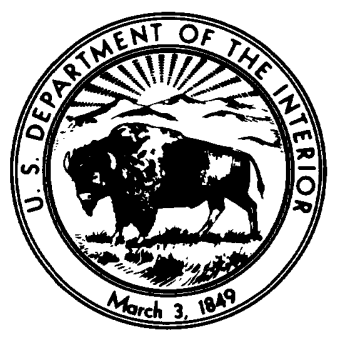

1992 


\section{U.S. DEPARTMENT OF THE INTERIOR \\ MANUEL LUJAN, JR., Secretary \\ U.S. GEOLOGICAL SURVEY}

Dallas L. Peck, Director

For additional information write to

Chief, Virginia District U.S. Geological Survey 3600 West Broad Street, Room 606

Richmond, VA 23230
Copies of this report can be purchased from:

U.S. Geological Survey

Books and Open-File Reports Section

Denver Federal Center, Box 25425

Denver, CO 80225 


\section{CONTENTS}

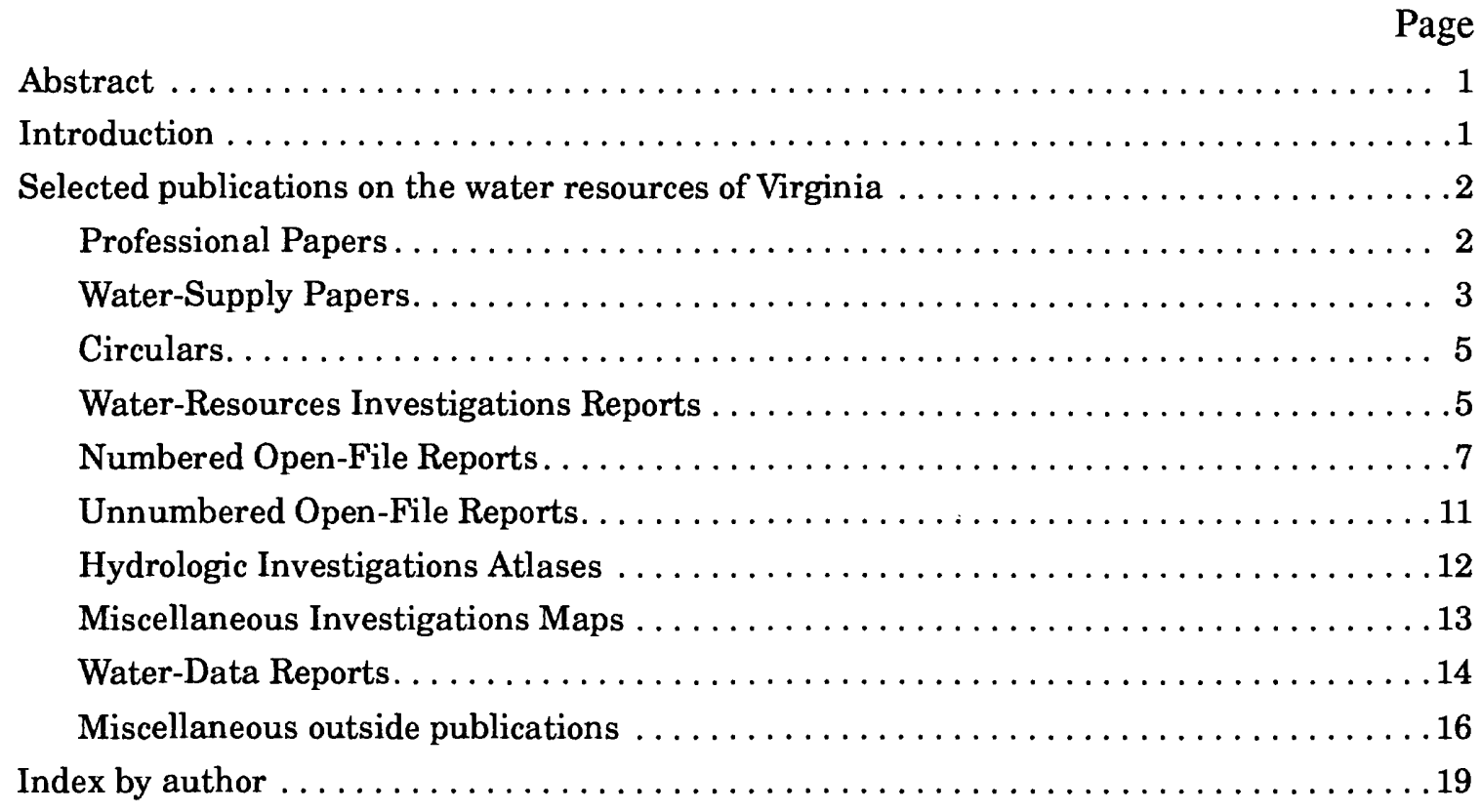




\title{
SELECTED U.S. GEOLOGICAL SURVEY PUBLICATIONS ON THE \\ WATER RESOURCES OF VIRGINIA, 1910-91
}

Compiled by Judith A. McFarland

\begin{abstract}
This report provides a list of selected U.S. Geological Survey publications related to the water resources of Virginia. Publication dates range from 1910 through 1991 . The report is organized by publication series and is arranged in alphabetical order by author(s) of the reports within each series.

\section{INTRODUCTION}

The U.S. Geological Survey (USGS), Virginia District receives numerous requests for data and information regarding its data-collection activities and interpretive projects. A list of reports published by the USGS is needed for those interested in information on the investigations related to the water resources of Virginia. This report presents a list of USGS publications from 1910 through 1991, including information at the beginning of each section on report availability.
\end{abstract}




\section{SELECTED PUBLICATIONS ON THE WATER RESOURCES OF VIRGINIA}

This section contains a listing of selected U.S. Geological Survey publications related to the water resources of Virginia. The report is organized by publication series, including Professional Papers, Water-Supply Papers, Circulars, Water-Resources Investigations Reports, Numbered Open-File Reports, Unnumbered Open-File Reports, Hydrologic Investigations Atlases, Miscellaneous Investigations Maps, and Water-Data Reports. Publications in each series are arranged in alphabetical order by author(s) of the reports within each series.

\section{Professional Papers}

Professional Papers can be purchased either as microfiche or paper copy and are available by mail from: U.S. Geological Survey, Map Distribution, Box 25286, Denver Federal Center, Denver, CO 80225 [phone number (303) 236-7477].

Back, William, 1966, Hydrochemical facies and ground-water flow patterns in northern part of the Atlantic Coastal Plain: U.S. Geological Survey Professional Paper 498-A, 42 p.

Brown, D.L., and Silvey, W.D., 1977, Artificial recharge to a fresh water-sensitive brackish-water sand aquifer, Norfolk, Virginia: U.S. Geological Survey Professional Paper 939, 53 p.

Brown, P.M., Miller, J.A., and Swain, F.M., 1972, Structural and stratigraphic framework, and spatial distribution of the permeability of the Atlantic Coastal Plain: U.S. Geological Survey Professional Paper 796, 79 p.

Brown, P.M., and Reid, M.S., 1976, Geologic evaluation of waste-storage potential in selected segments of the Mesozoic aquifer system below the zone of fresh water, Atlantic Coastal Plain, North Carolina through New Jersey: U.S. Geological Survey Professional Paper 881, 47 p.

Cushing, E.M., Kantrowitz, I.H., and Taylor, K.R., 1973, Water resources of the Delmarva Peninsula: U.S. Geological Survey Professional Paper 822, 58 p.

Giusti, E.V., 1962, Short papers in geology and hydrology, Articles 60-119--Art. 112, A relation between floods and drought flows in the Piedmont province in Virginia: U.S. Geological Survey Professional Paper 450-C, p. C128-C129.

Harsh, J.F., and Laczniak, R.J., 1990, Conceptualization and analysis of ground-water flow system in the Coastal Plain of Virginia and adjacent parts of Maryland and North Carolina: U.S. Geological Survey Professional Paper 1404-F, 100 p.

Meng, A.A., III, and Harsh, J.F., 1988, Hydrogeologic framework of the Virginia Coastal Plain: U.S. Geological Survey Professional Paper 1404-C, p. C1-C82.

Patterson, J.L., and Paulhus, J.L.H., 1975, Hurricane Agnes rainfall and floods, June-July 1972: U.S. Geological Survey Professional Paper 924, 403 p.

Pluhowski, E.J., 1972, Unusual temperature variations in two small streams in northern Virginia, in Geological Survey Research 1972, chap. B: U.S. Geological Survey Professional Paper 800-B, p. B225-B258. 
1972, Clear-cutting and its effect on the water temperature of a small stream in northern Virginia, in Geological Survey Research 1972, chap. C: U.S. Geological Survey Professional Paper 800-C, p. C257-C262.

Riggs, H.C., 1964, The relation of discharge to drainage area in the Rappahannock River basin, Virginia, in Geological Survey Research 1964, chap. B: U.S. Geological Survey Professional Paper 501-B, p. B165-B168.

1965, Effect of land use on the low flow of streams in Rappahannock County, Virginia, in Geological Survey Research 1965, chap. C: U.S. Geological Survey Professional Paper 525-C, p. C196-C198.

Runner, G.S., and Chin, E.H., 1980, Flood of April 1977 in the Appalachian Region of Kentucky, Tennessee, Virginia, and West Virginia: U.S. Geological Survey Professional Paper 1098, 43 p.

Sinnott, Allen, and Cushing, E.M., 1978, Summary appraisals of the Nation's ground-water resources Mid-Atlantic Region: U.S. Geological Survey Professional Paper 813-I, 32 p.

Williams, G.P., and Guy, H.P., 1973, Erosional and depositional aspects of Hurricane Camille in Virginia, 1969: U.S. Geological Survey Professional Paper 804, 80 p.

\section{Water-Supply Papers}

Water-Supply Papers can be purchased either as microfiche or paper copy and are available by mail from: U.S. Geological Survey, Map Distribution, Box 25286, Denver Federal Center, Denver, CO 80225 [phone number (303) 236-7477].

Anderson, D.G., 1970, Effects of urban development on floods in northern Virginia: U.S. Geological Survey Water-Supply Paper 2001-C, 22 p.

Bogart, D.B., 1960, Floods of August-October 1955, New England to North Carolina: U.S. Geological Survey Water-Supply Paper 1420, 854 p.

Cederstrom, D.J., 1957, Geology and ground-water resources of the York-James Peninsula, Virginia: U.S. Geological Survey Water-Supply Paper 1361, 237 p.

Durfor, C.N., 1961, Water quality and hydrology in the Fort Belvoir area, Virginia, 1954-55: U.S. Geological Survey Water-Supply Paper 1586-A, p. A1-A57.

Fisher, D.W., 1968, Annual variations in chemical composition of atmospheric precipitation, eastern North Carolina and southeastern Virginia: U.S. Geological Survey Water-Supply Paper 1535-M, $21 \mathrm{p}$.

Gambell, A.W., and Fisher, D.W., 1966, Chemical composition of rainfall, eastern North Carolina and southeastern Virginia: U.S. Geological Survey Water-Supply Paper 1535-K, p. K1-K41.

Grover, N.C., 1937, The floods of March 1936--Part 3, Potomac, James, and upper Ohio Rivers: U.S. Geological Survey Water-Supply Paper 800, 351 p.

Hamilton, P.A., Shedlock, R.J., and Phillips, P.J., 1992, Ground-water-quality assessment of the Delmarva Peninsula, Delaware, Maryland, and Virginia: Analysis of available water-quality data through 1987: U.S. Geological Survey Water-Supply Paper 2355-B, 65 p. 
Hayes, D.C., 1989, Low-flow characteristics of streams in Virginia: U.S. Geological Survey WaterSupply Paper 2374, 69 p.

Hirsch, R.M., Scott, A.G., and Wyant, Timothy, 1982, Investigations of trends in flooding in the Tug Fork basin of Kentucky, Virginia, and West Virginia: U.S. Geological Survey Water-Supply Paper $2203,37 \mathrm{p}$.

Johnston, P.M., 1962, Geology and ground-water resources of the Fairfax quadrangle, Virginia: U.S. Geological Survey Water-Supply Paper 1539-L, 61 p.

1964, Geology and ground-water resources of Washington, D.C., and vicinity: U.S. Geological Survey Water-Supply Paper 1776, 97 p.

Kull, T.K. and Hopkins, H.T., 1990, National water summary 1987--Hydrologic events and water supply and use: U.S. Geological Survey Water-Supply Paper 2350, p. 505-513.

Lohr, E.W., and Love, S.K., 1954, The industrial utility of public-water supplies in the United States, 1952--Part 1, States east of the Mississippi River: U.S. Geological Survey Water-Supply Paper $1299,639 \mathrm{p}$.

Meisler, Harold, Leahy, P.P., and Knobel, L.L., 1985, Effect of eustatic sea-level changes on saltwaterfreshwater relations in the Northern Atlantic Coastal Plain: U.S. Geological Survey Water-Supply Paper 2255, 28 p.

Meng, A.A., III, Harsh, J.F., and Kull, T.K., 1985, National water summary 1984--Hydrologic events, selected water-quality trends and ground-water resources: U.S. Geological Survey Water-Supply Paper 2275, p. 427-432.

Nuckels, E.H., and Prugh, B.J., Jr., 1991, National water summary 1988-89--Hydrologic events and floods and droughts: U.S. Geological Survey Water-Supply Paper 2375, p. 543-550.

Powell, J.D., and Hamilton, P.A., 1987, National water summary 1986--Hydrologic events and groundwater quality: U.S. Geological Survey Water-Supply Paper 2325, p. 509-514.

Powell, J.D., and Larson, J.D., 1985, Relation between ground-water quality and mineralogy in the coal-producing Norton Formation of Buchanan County, Virginia: U.S. Geological Survey WaterSupply Paper 2274, 30 p.

Prugh, B.J., Jr., and Scott, W.B., 1986, National water summary 1985--Hydrologic events and surfacewater resources: U.S. Geological Survey Water-Supply Paper 2300, p. 467-472.

Puckett, L.J., 1981, Dendroclimatic estimates of a drought index for northern Virginia: U.S. Geological Survey Water-Supply Paper 2080, 39 p.

Sanford, Samuel, 1910, Saline artesian waters of the Atlantic Coastal Plain, in Fuller, M.L., and others, Underground water papers: U.S. Geological Survey Water-Supply Papers 258, 123 p.

Trainer, F.W., and Watkins, F.A., Jr., 1975, Geohydrologic reconnaissance of the upper Potomac River basin: U.S. Geological Survey Water-Supply Paper 2035, 68 p.

U.S. Geological Survey, 1949, Floods of August 1940 in the southeastern States: U.S. Geological Survey Water-Supply Paper 1066, 554 p. 
1964, Floods of January-February 1957 in southeastern Kentucky and adjacent areas: U.S. Geological Survey Water-Supply Paper 1652-A, 195 p.

1984, A water-quality study of the tidal Potomac River and estuary--an overview: U.S. Geological Survey Water-Supply Paper 2233, 46 p.

1984, National water summary 1983--Hydrologic events and issues: U.S. Geological Survey Water-Supply Paper 2250, p. 224-226.

Vice, R.B., Guy, H.P., and Ferguson, G.E., 1969, Sediment movement in an area of suburban highway construction, Scott Run basin, Fairfax County, Virginia: U.S. Geological Survey Water-Supply Paper 1591-E, 41 p.

\section{Circulars}

Single copies of Circulars, still in print, are available free from: U.S. Geological Survey, Map Distribution, Box 25286, Denver Federal Center, Denver, CO 80225 [phone number (303) 236-7477].

Appel, C.A., and Bredehoeft, J.D., 1976, Status of ground-water modeling in the U.S. Geological Survey: U.S. Geological Survey Circular 737, 9 p.

Dodd, Kurt, Fuller, H.K., and Clarke, P.F., 1985, Guide to obtaining U.S. Geological Survey information: U.S. Geological Survey Circular 900, 35 p.

Imhoff, E.A., Friz, T.O., and LaFevers, J.R., 1976, A guide to State programs for the reclamation of surface-mined areas: U.S. Geological Survey Circular 731, 33 p.

Johnston, P.M., 1960, Ground-water supplies in shale and sandstone in Fairfax, Loudoun, and Prince William Counties, Virginia: U.S. Geological Survey Circular 424, 7 p.

Papadopulos, S.S., Bennett, R.R., Mack, F.K., and Trescott, P.C., 1974, Water from the Coastal Plain aquifers in the Washington, DC, metropolitan area: U.S. Geological Survey Circular 697,11 p.

U.S. Geological Survey, 1971, Index of surface-water records to September 30, 1970--Part 3, Ohio River basin: U.S. Geological Survey Circular 653, 71 p.

1983, Estimated water use in United States, 1980: U.S. Geological Survey Circular 1001, 56 p.

\section{Water-Resources Investigations Reports}

Water-Resources Investigations Reports can be purchased either as microfiche or paper copy and are available by mail from: U.S. Geological Survey, Books and Open-File Reports Section, Box 25425, Denver Federal Center, Denver, CO 80225 [phone number (303) 236-7476]. Reports with numbers less than -4000 may be purchased from the National Technical Information Service (NTIS), 5285 Port Royal Road, Springfield, VA 22161 [phone number (703) 487-4600]; the NTIS order number (if available) is given in parenthesis at the end of the citation. Further information about these reports may be obtained from the U.S. Geological Survey, Virginia District, 3600 West Broad Street, Room 606, Richmond, VA 23230 [phone number (804) 771-2427].

Carpenter, D.H., 1985, Cost-effectiveness of the Federal stream-gaging program in Virginia: U.S. Geological Survey Water-Resources Investigations Report 85-4345, $72 \mathrm{p}$. 
1990, Floods in West Virginia, Virginia, Pennsylvania, and Maryland, November 1985: U.S. Geological Survey Water-Resources Investigations Report 88-4213, 86 p.

Cosner, O.J., 1975, A predictive computer model of the Lower Cretaceous aquifer, Franklin area, southeastern Virginia: U.S. Geological Survey Water-Resources Investigations Report 51-74, $72 \mathrm{p}$. (PB-243-410/AS)

1976, Measured and simulated ground-water levels in the Franklin area, southeastern Virginia 1973-74: U.S. Geological Survey Water-Resources Investigations Report 76-83, 5 sheets, scale $1: 250,000$.

Doyle, W.H., Jr., Curwick, P.B., and Flynn, K.M., 1983, A flood model for the Tug Fork basin, Kentucky, Virginia, and West Virginia: U.S. Geological Survey Water-Resources Investigations Report 84-4014, $87 \mathrm{p}$.

Hamilton, P.A., and Larson, J.D., 1988, Hydrogeology and analysis of the ground-water-flow system in the Coastal Plain of southeastern Virginia: U.S. Geological Survey Water-Resources Investigations Report 87-4240, $175 \mathrm{p}$.

Hopkins, H.T., 1984, Water-resources reconnaissance of Prince William Forest Park, Virginia: U.S. Geological Survey Water-Resources Investigations Report 84-4009, $17 \mathrm{p}$.

1985, Ground-water availability along the Blue Ridge Parkway, Virginia: U.S. Geological Survey Water-Resources Investigations Report 84-4168, 154 p.

Kull, T.K., and Laczniak, R.J., 1987, Ground-water withdrawals from the confined aquifers in the coastal plain of Virginia, 1891-1983: U.S. Geological Survey Water-Resources Investigations Report 87-4049, $37 \mathrm{p}$.

Larson, J.D., and Powell, J.D., 1985, Hydrology and effects of mining in the upper Russell Fork basin, Buchanan and Dickenson Counties, Virginia: U.S. Geological Survey Water-Resources Investigations Report 85-4238, $63 \mathrm{p}$.

Laczniak, R.J. and Meng, A.A., III, 1988, Ground-water resources of the York-James Peninsula of Virginia: U.S. Geological Survey Water-Resources Investigations Report 88-4059, 178 p.

Lloyd, O.B., Jr., Larson, J.D., and Davis, R.W., 1985, Summary of northern Atlantic Coastal Plain hydrology and its relation to disposal of high-level radioactive waste in buried crystalline rock: U.S. Geological Survey Water-Resources Investigations Report 85-4146, 80 p.

Lynch, D.D., and Dise, N.B., 1985, Sensitivity of stream basins in Shenandoah National Park to acid deposition: U.S. Geological Survey Water-Resources Investigations Report 85-4115, 61 p.

Lynch, D.D., 1987, Hydrologic conditions and trends in Shenandoah National Park, Virginia, 1983-84: U.S. Geological Survey Water-Resources Investigations Report 87-4131, 115 p.

Miller, E.M., 1978, Technique for estimating the magnitude and frequency of Virginia floods: U.S. Geological Survey Water-Resources Investigations Report 78-5, 83 p.

Nelms, D.L., and Richardson, D.L., 1990, Geohydrology and the occurrence of volatile-organic compounds in ground water, Culpeper basin of Prince William County, Virginia: U.S. Geological Survey Water-Resources Investigations Report 90-4032, 94 p.

Powell, J.D., and Abe, J.M., 1985, Availability and quality of ground water in the Piedmont province of Virginia: U.S. Geological Survey Water-Resources Investigations Report 85-4235, 32 p. 
Powell, J.D., Wright, W.G., Nelms, D.L., and Ahlin, R.J., 1990, Ground-water contamination and movement at the Defense General Supply Center, Richmond, Virginia: U.S. Geological Survey Water-Resources Investigations Report 90-4113, 36 p.

Rogers, S.M., and Powell, J.D., 1983, Quality of ground water in southern Buchanan County, Virginia: U.S. Geological Survey Water-Resources Investigations Report 82-4022, 36 p.

Scott, A.G., 1984, Analysis of characteristics of simulated flows from small surface-mined and undisturbed Appalachian watersheds in the Tug Fork basin of Kentucky, Virginia, and West Virginia: U.S. Geological Survey Water-Resources Investigations Report 84-4151, 169 p.

Wright, W.G., 1985, Effects of fracturing on well yields in the coalfield areas of Wise and Dickenson Counties, southwestern Virginia: U.S. Geological Survey Water-Resources Investigations Report 85-4061, 21 p.

1990, Ground-water hydrology and quality in the Valley and Ridge and Blue Ridge physiographic provinces of Clarke County, Virginia: U.S. Geological Survey Water-Resources Investigations Report 90-4134, $61 \mathrm{p}$.

Wright, W.G., and Powell, J.D., 1990, Assessment of ground-water contamination from a leaking underground storage tank at a Defense Supply Center near Richmond, Virginia: U.S. Geological Survey Water-Resources Investigations Report 90-4091, 38 p.

\section{Numbered Open-File Reports}

Open-File Reports can be purchased either as microfiche or paper copy and are available by mail from: U.S. Geological Survey, Books and Open-File Reports Section, Box 25425, Denver Federal Center, Denver, CO 80225 [phone number (303) 236-7476]. Further information about these reports may be obtained from the U.S. Geological Survey, Virginia District, 3600 West Broad Street, Room 606, Richmond, VA 23230 [phone number (804) 771-2427].

Blanchard, S.F., Coupe, R.H., Jr., and Woodward, J.C., 1982, Water quality of the tidal Potomac River and estuary, Hydrologic Data Report, 1981 Water Year: U.S. Geological Survey Open-File Report 82-575, $304 \mathrm{p}$.

Brown, G.A., 1981, Water resources of Prince William Forest Park: U.S. Geological Survey Open-File Report 80-964, 2 sheets, scale 1:24,000.

Carrington, N.R., 1986, Selected publications on the water resources of Virginia: U.S. Geological Survey Open-File Report 86-418W, 34 p.

Carter, Virginia, and Clark, C.P., 1978, Map of roads and ditches of the Great Dismal Swamp, Virginia and North Carolina: U.S. Geological Survey Open-File Report 78-86, 1 sheet, scale 1:126,720.

Farrington, S.T., Carrington, N.R., and Daniels, W.V., Jr., 1984, Water-level hydrographs for observation wells in Virginia, 1982: U.S. Geological Survey Open-File Report 83-134, 167 p.

Froelich, A.J., Johnston, R.H., and Langer, W.H., 1979, Preliminary report on the ancestral Potomac River deposits in Fairfax County, Virginia, and their potential hydrogeologic significance: U.S. Geological Survey Open-File Report 78-544, 37 p. 
Hamilton, P.A., Shedlock, R.J., and Phillips, P.J., 1989, Ground-water assessment of the Delmarva Peninsula, Delaware, Maryland, and Virginia--Analysis of available water-quality data through 1987: U.S. Geological Survey Open-File Report 89-34, 71 p.

Harlow, G.E., Jr., and LeCain, G.D., 1991, Hydraulic characteristics of, and ground-water-flow in, coalbearing rocks of southwestern Virginia: U.S. Geological Survey Open-File Report 91-250, 48 p.

Harsh, J.F., 1980, Ground-water hydrology of James City County, Virginia: U.S. Geological Survey Open-File Report 80-961, 73 p.

Hendrick, W.E., Jr., 1982, Summary of hydrologic data collected at Wytheville National Fish Hatchery No. 2, Max Meadows, Virginia, 1976 to 1979: U.S. Geological Survey Open-File Report 82-686, 28 p.

Hirsch, R.M., 1978, Risk analyses for water supply--Occoquan Reservoir, Fairfax and Prince William Counties, Virginia: U.S. Geological Survey Open-File Report 78-452, 61 p.

Hopkins, H.T., Bower, R.F., Abe, J.M., and Harsh, J.F., 1981, Potentiometric surface map for the Cretaceous aquifer, Virginia Coastal Plain: U.S. Geological Survey Open-File Report 80-965, 1 sheet, scale 1:500,000.

Hufschmidt, P.W., 1984, Description and evaluation of the Information Transfer Workshop Series--Coal Hydrology in Virginia: U.S. Geological Survey Open-File Report 83-852, 23 p.

Hufschmidt, P.W., and others, 1981, Hydrology of Area 16, Eastern Coal Province, Virginia-Tennessee: U.S. Geological Survey Open-File Report 81-204, 68 p.

Johnston, R.H., 1978, Probable yields of wells in the bedrock aquifers of Fairfax County, Virginia: U.S. Geological Survey Open-File Report 78-267, 1 pl., 2 tab., scale 1:48,000.

Johnston, R.H., and Froelich, A.J., 1977, Map showing lithofacies and inferred subsurface distribution of channel-fill sands in the Potomac Group in Fairfax County, Virginia: U.S. Geological Survey Open-File Report 77-287, 8 p.

Johnston, R.H., and Larson, J.D., 1976, Preliminary appraisal of ground water in the Franconia area, Virginia: U.S. Geological Survey Open-File Report 76-400, 19 p.

1977, Potentiometric surface maps and water-level change map for the lower aquifer of the Cretaceous Potomac Group in Fairfax County, Virginia: U.S. Geological Survey Open-File Report 77-284, 7 p., scale: 1:4,000.

1979, Principal sources of ground water in Fairfax County, Virginia: U.S. Geological Survey Open-File Report 79-211, 1 sheet.

Johnston, R.H., and Van Driel, J.N., 1978, Susceptibility of Coastal Plain aquifers to contamination, Fairfax County, Virginia--A computer composite map: U.S. Geological Survey Open-File Report 78-265, 1 pl., scale 1:48,000.

1979, Evaluation of potential yield of water wells in bedrock aquifers, Fairfax County, Virginia-computer composite map: U.S. Geological Survey Open-File Report 79-525, 2 pls., scale 1:48,000.

Knobel, L.L., 1985, Ground-water quality data for the Atlantic Coastal Plain: New Jersey, Delaware, Maryland, Virginia, and North Carolina: U.S. Geological Survey Open-File Report 85-154, 84 p. 
Larson, J.D., 1978, Hydrogeology of the observation well site at U.S. Geological Survey National Headquarters, Reston, Virginia: U.S. Geological Survey Open-File Report 78-144, 35 p.

1978, Chemical quality of ground water in Fairfax County, Virginia: U.S. Geological Survey Open-File Report 78-268, 2 pl., 3 tab., scale 1:48,000.

1978, Chemical composition of streams during low flow--Fairfax County, Virginia: U.S. Geological Survey Open-File Report 78-719, 31 p.

1981, Distribution of saltwater in the Coastal Plain aquifers of Virginia: U.S. Geological Survey Open-File Report 81-1013, 25 p.

1985, Selected hydrologic data for the Powell River basin in Wise County, Virginia: U.S. Geological Survey Open-File Report 85-186, 22 p.

Larson, J.D., and Froelich, A.J., 1977, Map showing extent, altitude at base, and thickness of the Potomac Group in Fairfax County, Virginia: U.S. Geological Survey Open-File Report 77-286, 4 p.

Larson, J.D., and Laczniak, R.J., 1991, Ground-water use and levels in the southern Coastal Plain of Virginia: U.S. Geological Survey Open-File Report 91-187, 165 p.

Lescinsky, J.B., 1987, Flood of November 1985 in West Virginia, Pennsylvania, Maryland, and Virginia: U.S. Geological Survey Open-File Report 86-486, 33 p.

Lewis, T.A., 1981, Solid waste disposal sites in Fairfax County and vicinity, Virginia: U.S. Geological Survey Open-File Report 81-64.

Lichtler, W.F., and Wait, R.L., 1974, Summary of the ground-water resources of the James River basin, Virginia: U.S. Geological Survey Open-File Report 74-139, 54 p.

Lichtler, W.F., and Walker, P.N., 1974, Hydrology of the Dismal Swamp, Virginia-North Carolina: U.S. Geological Survey Open-File Report 74-39, 50 p.

Lloyd, O.B.,Jr., Barnes, C.R., and Woodside, M.D., 1991, National water-quality assessment program --The Albemarle-Pamlico drainage: U.S. Geological Survey Open-File Report 91-156, 2 p.

McGreevy, L.J., Hyatt, G.J., and Cockey, E.J., 1986, Water resources activities of the U.S. Geological Survey, Mid-Atlantic District, 1984-1986: U.S. Geological Survey Open-File Report 86-490, 129 p.

Meisler, Harold, 1981, Preliminary delineation of salty ground water in the northern Atlantic Coastal Plain: U.S. Geological Survey Open-File Report 81-71, 39 p.

Miller, E.M, 1977, Annual maximum stages and discharges of Virginia streams: U.S. Geological Survey Open-File Report 77-720, 250 p.

Mohler, E.H., Jr., 1977, Map showing drainage basins and locations of streamflow-measuring sites, Fairfax County, Virginia: U.S. Geological Survey Open-File Report 77-270, 1 sheet, scale 1:48,000.

Mohler, E.H., Jr., and Hagan, G.F., 1981, Low flow of streams in Fairfax County, Virginia: U.S. Geological Survey Open-File Report 81-63, 30 p.

Mohler, E.H., Jr., and Novak, C.E., 1978, 100-year flood map, Fairfax County, Virginia: U.S. Geological Survey Open-File Report 78-767, 1 pl., scale 1:48,000. 
Mulheren, M.P., Larson, J.D., and Hopkins, H.T., 1982, An index of geophysical well logging in Virginia: U.S. Geological Survey Open-File Report 82-432, 34 p.

Powell, J.D., and Hamilton, P.A., 1987, Virginia ground-water quality: U.S. Geological Survey OpenFile Report 87-759, 7 p.

Powell, J.D., Speiran, G.K., and Anderson, G.S., 1988, U.S. Geological Survey ground-water studies in Virginia: U.S. Geological Survey Open-File Report 88-135, 2 p.

Prugh, B.J., Jr., Nuckels, E.H., and Humphrey, C.G., 1991, Annual maximum stages and discharges of selected streams in Virginia through 1990: U.S. Geological Survey Open-File Report 90-587, 442 p.

Richardson, D.L., Laczniak, R.J., and Hamilton, P.A., 1988, Evaluation of municipal with drawals from the confined aquifers of southeastern Virginia: U.S. Geological Survey Open-File Report 88-723, $50 \mathrm{p}$.

Rogers, S.M., 1977, A water-quality assessment of the Northeast Creek and Desper Creek watersheds, South Anna River basin, Louisa County, Virginia: U.S. Geological Survey Open-File Report 77-460, $38 \mathrm{p}$.

Rogers, S.M., and Hufschmidt, P.W., 1980, Quality of surface water in the coal-mining area of southwestern Virginia: U.S. Geological Survey Open-File Report 80-769, 2 sheets.

Scott, A.G., 1980, An interim report on the investigation of flooding in the Tug Fork basin of Kentucky, Virginia, and West Virginia: U.S. Geological Survey Open-File Report 80-1188, 116 p.

Shedlock, R.J., Phillips, P.J., Bachman, L.J., and Hamilton, P.A., 1990, Strategy for ground-water quality assessment of the Delmarva Peninsula, Delaware, Maryland, and Virginia--Second National Symposium on Water Quality: U.S. Geological Survey Open-File Report 89-409, p. 88.

Soule, P.L., 1976, Flood-plain delineation for Cameron Run basin, Fairfax County-Alexandria City, Virginia: U.S. Geological Survey Open-File Report 76-433, 94 p.

1976, Flood-plain delineation for Difficult Run basin, Fairfax County, Virginia: U.S. Geological Survey Open-File Report 76-459, 184 p.

1977, Flood-plain delineation for Accotink Creek basin, Fairfax County, Virginia: U.S. Geological Survey Open-File Report 76-442, 119 p.

1977, Flood-plain delineation for Pohick Creek basin, Fairfax County, Virginia: U.S. Geological Survey Open-File Report 76-444, 121 p.

1977, Flood-plain delineation for Bull Run, Little Rocky Run, Johnny Moore Creek, and Popes Head Creek basins, Fairfax County, Virginia: U.S. Geological Survey Open-File Report 77-329, $156 \mathrm{p}$.

1978, Flood-plain delineation for Bullneck, Scott, Dead, and Pimmit Run basins, Fairfax City, Virginia: U.S. Geological Survey Open-File Report 78-260, 77 p.

1978, Flood-plain delineation for Horsepen Run, Sugarland Run, Pond Branch, Clarks Branch, and Mines Run Branch basins, Fairfax County, Virginia: U.S. Geological Survey Open-File Report 78-1028, 97 p. 
1978, Flood-plain delineation for Occoquan River, Wolf Run, Sandy Run, Elk Horn Run, Giles Run, Kanes Creek, Racoon Creek, and Thompson Creek, Fairfax County, Virginia: U.S. Geological Survey Open-File Report 79-215, 118 p.

Wright, W.G., and Powell, J.D., 1990, Preliminary investigation of soil and ground-water contamination at the U.S. Army Petroleum Training Facility, Fort Lee, Virginia, SeptemberOctober 1989: U.S. Geological Survey Open-File Report 90-387, 28 p.

\section{Unnumbered Open-File Reports}

Information on the availability of unnumbered Open-File Reports can be obtained from the U.S. Geological Survey, Virginia District, 3600 West Broad Street, Room 606, Richmond VA 23230 [phone number (804) 771-2427].

Anderson, D.G., 1961, Flood inundation study of the Cameron Run basin, Virginia: U.S. Geological Survey Open-File Report.

1968, Effects of urban development on floods in northern Virginia: U.S. Geological Survey Open-

File Report, 26 p.

Bain, G.L., 1973, Feasibility study of East Coast Triassic basins for waste storage: U.S. Geological Survey Open-File Report.

Brown, D.L., 1968, Memorandum report on test drilling at Norfolk, Virginia: U.S. Geological Survey Open-File Report, 28 p.

1971, Geophysical logs of test well 1, Norfolk, Virginia: U.S. Geological Survey Open-File Report.

Camp, J.D., and Miller, E.M., 1970, Flood of August 1969 in Virginia: U.S. Geological Survey Open-File Report, $120 \mathrm{p}$.

Cederstrom, D.J., 1969, Geology and ground-water resources of the Middle Peninsula, Virginia: U.S. Geological Survey Open-File Report.

Cosner, O.J., and Brown, G.A., 1970, Potentiometric surface of the Lower Cretaceous aquifer, Franklin area, Virginia: U.S. Geological Survey Open-File Report.

Cosner, O.J., and Horwich, E., 1974, Grid-coordinate generating program: U.S. Geological Survey Open-File Report.

Miller, E.M., 1953, Summary of flood discharges for drainage areas under 100 square miles in Virginia: U.S. Geological Survey Open-File Report, 11 p.

1969, Floods in Virginia, magnitude and frequency: U.S. Geological Survey Open-File Report.

Miller, E.M., and Kapinos, F.P., 1966, Summary of flood discharge for drainage areas under 120 square miles in Virginia: U.S. Geological Survey Open-File Report, 13 p.

1967, 1967 index of gaging stations in Virginia: U.S. Geological Survey Open-File Report.

1967, Flood of August 1967 in the Washington, D.C., metropolitan area: U.S. Geological Survey

Open-File Report, 83 p. 
1970, Flood of July 22, 1969, in northern Virginia: U.S. Geological Survey Open-File Report, 35 p.

Nuckels, E.H., 1970, Virginia streamflow data program analysis: U.S. Geological Survey Open-File Report, 54 p.

Phelan, D.J., Carrington, N.R., and Hyatt, G.J., 1983, Water Resources Activities of the U.S. Geological Survey Mid-Atlantic District 1981-83: U.S. Geological Survey Open-File Report, 98 p.

Tice, R.H., and Others, 1957, Flood of January-February 1957 in south west Virginia: U.S. Geological Survey Open-File Report, $45 \mathrm{p}$.

\section{Hydrologic Investigations Atlases}

Hydrologic Investigations Atlases can be purchased by mail from: U.S. Geological Survey, Map Distribution, Box 25286, Denver Federal Center, Denver, CO 80225 [phone number (303) 236-7477].

Brown, G.A., and Cosner, O.J., 1974, Ground-water conditions in the Franklin area, southeastern Virginia: U.S. Geological Survey Hydrologic Investigations Atlas 538, 3 sheets, scale 1:125,000.

DeBuchanne, G.D., 1968, Ground-water resources of the James, York, and Rappahannock River basins of Virginia west of the Fall Line: U.S. Geological Survey Hydrologic Investigations Atlas 283, 1 sheet, scale 1:500,000.

1968, Ground-water resources of the Eastern Shore of Virginia and the James, York, and Rappahannock River basins of Virginia east of the Fall Line: U.S. Geological Survey Hydrologic lnvestigations Atlas 284, 2 sheets, scale 1:500,000.

Miller, E.M., 1969, Flood of August 1969, Bon Air quadrangle, Richmond, Virginia: U.S. Geological Survey Hydrologic Investigations Atlas 409, 1 sheet, scale 1:24,000.

1969, Flood of August 1969, Richmond quadrangle, Richmond, Virginia: U.S. Geological Survey Hydrologic Investigations Atlas 410, 1 sheet, scale 1:24,000.

1969, Flood of August 1969, Drewrys Bluff quadrangle, Richmond, Virginia: U.S. Geological Survey Hydrologic Investigations Atlas 411, 1 sheet, scale 1:24,000.

Miller, E.M., and Walker, P.N., 1973, Flood of October 1972 and Petersburg and Colonial Heights, Virginia: U.S. Geological Survey Hydrologic Investigations Atlas 505, 1 sheet, scale 1:24,000.

Rapp, D.H., 1968, Floods on Johns and Craig Creeks, in Craig County, Virginia: U.S. Geological Survey Hydrologic Investigations Atlas 326, 1 sheet, scale 1:12,000.

Runner, G.S., 1969, Flood of August 1969 on Maury River at Buena Vista, Virginia: U.S. Geological Survey Hydrologic Investigations Atlas 412, 1 sheet, scale 1:24,000.

Schneider, W.J., and others, 1965, Water resources of the Appalachian Region, Pennsylvania to Alabama: U.S. Geological Survey Hydrologic Investigations Atlas 198, 11 sheets, sheet 1--scale $1: 7,000,000$, sheet 2-11--1:2,500,000. 


\section{Miscellaneous Investigations Maps}

Miscellaneous Investigations Maps can be purchased from: U.S. Geological Survey, Map Distribution, Box 25286, Denver Federal Center, Denver, CO 80225 [phone number (303) 236-7477].

Froelich, A.J., in press, Folio of geologic and hydrologic maps for land-use planning in the Coastal Plain of Fairfax County and vicinity, Virginia: U.S. Geological Survey Miscellaneous Investigations Map I- 1423.

1985, Map and geotechnical properties of surface materials of the Culpeper basin and vicinity, Virginia and Maryland: U.S. Geological Survey Miscellaneous Investigations Maps I-1313-E, scale $1: 125,000$.

Froelich, A.J., and Langer, W.H., 1981, Map showing geologic provinces, land forms, drainage basin characteristics, and flooding in Fairfax County, Virginia: U.S. Geological Survey Miscellaneous Investigations Map I-1421, scale 1:48,000.

Froelich, A.J., and Leavy, B.D., 1982, Map showing mineral resources of the Culpeper basin, Virginia and Maryland--Availability and planning for future needs: U.S. Geological Survey Miscellaneous Investigations Map I-1313-B, scale 1:125,000.

Laczniak, R.J., and Zenone, Chester, 1984, Ground-water resources of the Culpeper basin, Virginia and Maryland: U.S. Geological Survey Miscellaneous Investigations Map I-1313-F, scale 1:125,000.

Leavy, B.D., 1984, Map showing planar and linear features in the Culpeper basin and vicinity, Virginia and Maryland: U.S. Geological Survey Miscellaneous Investigations Map I-1313-G, scale $1: 125,000$.

Leavy, B.D., Froelich, A.J., and Abram, E.C., 1983, Bedrock map and geotechnical properties of rocks of the Culpeper basin and vicinity, Virginia and Maryland: U.S. Geological Survey Miscellaneous Investigations Map I-1313-C, scale 1:125,000.

Lynch, D.D., Nuckels, E.H., and Zenone, Chester, 1987, Low-flow characteristics and chemical quality of streams in the Culpeper geologic basin, Virginia and Maryland: U.S. Geological Survey Miscellaneous Investigations Map I-1313-H, 2 sheets, scale 1:125,000.

Morsches, S.A., and Zenone, Chester, 1981, Index map of flood studies, Culpeper basin, Virginia and Maryland: U.S. Geological Survey Miscellaneous Investigations Map I-1313-A, scale 1:125,000.

Posner, Alex, and Zenone, Chester, 1983, Chemical quality of ground water in the Culpeper basin, Virginia and Maryland: U.S. Geological Survey Miscellaneous Investigations Map I-1313-D, scale $1: 125,000$.

Zenone, Chester, and Larson, J.D., 1982, Ground-water resources of Fairfax County and vicinity, Virginia, and some aspects of their development: U.S. Geological Survey Miscellaneous Investigations Map I-1473, scale 1:48,000. 


\section{Water-Data Reports}

Water-Data Reports listed below can be purchased either as microfiche or paper copy and are available by mail from: National Technical Information Service (NTIS), 5285 Port Royal Road, Springfield, VA 22161 [phone number (703) 487-4600]. The NTIS-order number (if available) is given in parentheses at the end of the citation. Further information about these reports can be obtained from the U.S. Geological Survey, Virginia District, 3600 West Broad Street, Room 606, Richmond, VA 23230 [phone number (804) 771-2427].

U.S. Geological Survey, 1961, Surface water records of Virginia, 1961.

1962, Surface water records of Virginia, 1962.

1963, Surface water records of Virginia, 1963.

1964, Surface water records of Virginia, 1964, $193 \mathrm{p}$.

1964, Water quality records in Virginia and West Virginia, 1964, $52 \mathrm{p}$.

1965, Water resources data for Virginia, 1965--Part 1, surface-water records; Part 2, waterquality records, $218 \mathrm{p}$.

1966, Water resources data for Virginia, 1966--Part 1, surface-water records; Part 2, waterquality records, $232 \mathrm{p}$.

1967, Water resources data for Virginia, 1967--Part 1, surface-water records; Part 2, waterquality records, $234 \mathrm{p}$.

1968, Water resources data for Virginia, 1968--Part 1, surface-water records; Part 2, waterquality records, $326 \mathrm{p}$.

1969, Water resources data for Virginia, 1969--Part 1, surface-water records; Part 2, waterquality records, $311 \mathrm{p}$.

1970, Water resources data for Virginia, 1970--Part 1, surface-water records; Part 2, waterquality records, $299 \mathrm{p}$.

1971, Water resources data for Virginia, 1971--Part 1, surface-water records; Part 2, waterquality records; and Part 3, ground-water records, 305 p. (PB-289-509)

1972, Water resources data for Virginia, 1972--Part 1, surface-water records; Part 2, waterquality records; and Part 3, ground-water records, 326 p. (PB-289-510)

1973, Water resources data for Virginia, 1973--Part 1, surface-water records; Part 2, waterquality records; and Part 3, ground-water records, 324 p. (PB-289-511)

1974, Water resources data for Virginia, 1974--Part 1, surface-water records; Part 2, waterquality records; and Part 3, ground-water records, 338 p. (PB-289-512)

1976, Water resources data for Virginia--water year 1975: U.S. Geological Survey Water-Data Report VA-75-1, 346 p. (PB-259-196) 
1977, Water resources data for Virginia--water year 1976: U.S. Geological Survey Water-Data Report VA-76-1, 363 p. (PB-272-772)

1978, Water resources data for Virginia--water year 1977: U.S. Geological Survey Water-Data Report VA-77-1, 391 p. (PB-287-706)

1979, Water resources data for Virginia--water year 1978: U.S. Geological Survey Water-Data Report VA-78-1, 413 p. (PB-80-116-650)

1980, Water resources data for Virginia--water year 1979: U.S. Geological Survey Water-Data Report VA-79-1. (PB-80-220-254)

1981, Water resources data for Virginia--water year 1980: U.S. Geological Survey Water-Data Report VA-80-1. (PB-82-113-416)

Prugh, B.J., Jr., Easton, F.J., and Lynch D.D., 1982, Water resources data for Virginia--water year 1981: U.S. Geological Survey Water-Data Report VA-81-1. (PB-83-103-192)

1983, Water resources data for Virginia--water year 1982: U.S. Geological Survey Water-Data Report VA-82-1, 460 p. (PB-84-118-553)

1984, Water resources data for Virginia--water year 1983: U.S. Geological Survey Water-Data Report VA-83-1, 442 p. (PB-84-224-542)

1985, Water resources data for Virginia--water year 1984: U.S. Geological Survey Water-Data Report VA-84-1, 405 p. (PB-85-242-105)

1986, Water resources data for Virginia--water year 1985: U.S. Geological Survey Water-Data Report VA-85-1, 398 p. (PB-85-111-852)

1987, Water resources data for Virginia--water year 1986: U.S. Geological Survey Water-Data Report VA-86-1, 395 p. (PB-88-101-423)

1988, Water resources data for Virginia--water year 1987: U.S. Geological Survey Water-Data Report VA-87-1, 441 p. (PB-89-114-375)

1989, Water resources data for Virginia--water year 1988: U.S. Geological Survey Water-Data Report VA-88-1, 447 p. (PB-89-207-591)

Prugh, B.J., Jr., Easton, F.J., and Belval, D.L., 1990, Water resources data for Virginia--water year 1989: U.S. Geological Survey Water-Data Report VA-89-1. (PB-90-220-377)

1991, Water resources data for Virginia--water year 1990, Vol. 1, surface water and surface-water quality records: U.S. Geological Survey Water-Data Report VA-90-1, 407 p. (PB-91-200-741)

1991, Water resources data for Virginia--water year 1990, Vol. 2, ground water and ground-water quality records: U.S. Geological Survey Water-Data Report VA-90-2, 389 p. (PB-91-176-131) 


\section{Miscellaneous Outside Publications}

Publications by USGS personnel in non-USGS publications are not available for purchase from the USGS.

Augenstein, T.W., Richardson, D.L., and Terry, J.E., Jr., 1988, Budget, A water-use supply and demand program to assist water-use planners: American Water Resources Association Symposium, Poster, Tucson, Ariz., 1988.

Augenstein, T.W., Terziotti, Silvia, Hom, P.J., 1990, Proximity analysis--A tool for comparing data bases [abs.]: U.S. Geological Survey National Computer Technology Meeting, San Antonio, Tex., 1990 , p. 2.

Bachman, L.J., Denver, J.M., and Hamilton, P.A., 1991, Multivariate statistical analysis of geochemical processes in shallow ground water in the Delmarva Peninsula, Delaware, Maryland, and Virginia: EOS Transactions, American Geophysical Union, 1991, p. 114.

Brown, D.L., 1971, Techniques for quality-of-water interpretations from calibrated geophysical logs, Atlantic coastal area: Ground Water, v. 9, no. 4, p. 25-38.

Focazio, M.J., 1990, Application of a geographic information system to the analysis of ground-water resources in the Coastal Plain of Virginia: International Conference on Application of a Geographic Information System-Simulation Model and Knowledge-Based Systems for Landuse Management, Blacksburg, Va., 1990, Proceedings, p. 351-359.

Hamilton, P.A., 1988, Regional effects of pumpage in the Coastal Plain of southeastern Virginia, in Critical water issues and computer applications: American Society of Civil Engineers, New York, p. 168-170.

1988, Objectives of and approaches used in the ground-water-quality assessment of the Delmarva Peninsula [abs.], in Briefing papers of the Virginia Waters--Current Developments, 1988 Water Resources Research Forum, Richmond, Va., 1988, p. 48.

1990, Relations between land use and nitrate concentrations in shallow ground water, Delmarva Peninsula [abs.], in Collected abstracts of the Virginia Water Resources Conference, Richmond, Va., 1990, p. 30 .

1991, Relations between ground-water flow, land use and shallow ground-water quality, Delmarva Peninsula, Delaware, Maryland, and Virginia [abs.], in Collected abstracts of the Virginia Water Resources Conference, Richmond, Va., 1991, p. 15.

Hamilton, P.A., and Denver, J.M., 1990, Effects of land use and ground-water flow on shallow groundwater quality, Delmarva Peninsula, Delaware, Maryland, and Virginia: Groundwater, v. 28, no. 5, p. 789.

Hamilton, P.A., and Laczniak, R.J., 1986, Application of a ground-water flow model to assess regional effects of ground-water withdrawals on Chesapeake Bay: Third Annual Regional Ground-Water Conference, National Water Well Association, Proceedings, $17 \mathrm{p}$.

Hamilton, P.A., and Shedlock, R.J., 1989, Relations between land use and nitrate concentrations in shallow ground water, Delmarva Peninsula: U.S. Geological Survey Yearbook Fiscal Year 1989, p. 38-41. 
Harlow, G.E., Jr., and Nelms, D.L., 1989, Use of digitization to establish hydrogeologic units in the Piedmont and Blue Ridge physiographic provinces, Virginia to New Jersey [abs.], in Program with abstracts for the Conference on Ground Water in the Piedmont of the Eastern United States, Charlotte, N.C., 1989, p. 24.

1989, Use of a geographic information system to identify hydrogeologic units in the Piedmont and Blue Ridge physiographic provinces, Virginia to New Jersey: Conference on Ground water in the Piedmont of the Eastern United States, Charlotte, N.C., 1989, Proceedings, [in press].

Larson, J.D., 1984, A water resource appraisal of the Powell River basin in Wise County, Virginia: 1983 Powell River Project Symposium, 1984, p. 8-14.

Nelms, D.L., and Richardson, D.L., 1988, Geographic information system for the analysis of volatile organic contamination in the Triassic basin of Prince William County, Virginia [abs.], in Briefing papers of the Virginia Waters--Current Developments, 1988 Water Resources Research Forum, Richmond, Va., 1988, p. 22.

1988, Geographic information system for the assessment of contamination by volatile organic compounds in the Triassic basin of Prince William County, Virginia [abs.]: U.S. Geological Survey, Water Resources Division, Northeastern Region, Ground-Water Flow and Quality Conference, Niagara Falls, N.Y., 1988, p. 41.

Phillips, P.J., Shedlock, R.J., and Hamilton, P.A., in press, 1989, National Water-Quality Assessment Program activities on the Delmarva Peninsula in parts of Delaware, Maryland, and Virginia, in Gohn, G.S., ed., U.S. Geological Survey Workshop on the Geology and Geohydrology of the Atlantic Coastal Plain, 1988, U.S. Geological Circular 1059.

Powell, J.D., 1984, Geochemical models of the relation between water quality and mineralogy in coal producing strata of southwestern Virginia [abs.]: National Water Well Association, Practical Applications of Ground-Water Geochemistry--Applied Geochemistry Workshop, Banff, Alberta, Canada, 1984, $1 \mathrm{p}$.

1988, Origin and influence of coal mine drainage on streams of the United States: Environmental Geology Water Science, v. 11, no. 2, p. 141-152.

Powell, J.D., Hufschmidt, P.W., and Larson, J.D., 1982, Geochemistry of ground water in the coalproducing area of southwest Virginia: 1982 Symposium on Surface Mining Hydrology, Sedimentation and Reclamation, University of Kentucky, Lexington, Ky., 1982, p. 439-444.

Powell, J.D., Wright, W.G., Nelms, D.L., and Ahlin, R.J., 1990, Vertical and horizontal distribution of volatile organic contamination in a multi-aquifer system [abs.]: USA/USSR Joint Conference on Environment Hydrology, Leningrad, USSR, 1990, 1 p.

Richardson, D.L., and Nelms, D.L., 1989, Geographic information system for the assessment of contamination by volatile organic compounds in the Triassic basin of Prince William County, Virginia [abs.]: National Academy of Sciences, U.S. Geological Survey, and the Association of American State Geologists, Geographic Information System Symposium--Integrating Technology and Geoscience Applications, Denver, Colo., 1988, p. 137.

Shedlock, R.J., Phillips, P.J., Backman, L.J., Hamilton, P.A., and Denver, J.M., in press, Influence of wetlands on regional water-quality patterns in the Delmarva Peninsula of Delaware, Maryland, and Virginia, in Collected abstracts of the 1991 Society of Wetland Scientists Meeting, Ann Arbor, Mich. 
Speiran, G.K., 1991, Processes controlling nitrate concentrations in ground-water discharge [abs.]: First Eastern Shore Natural Resources Symposium, Cape Charles, Va., 1991, 2 p.

Woodside, M.D., 1990, Copper sulfate treatment of algae in an urban pond in Blacksburg, Virginia [abs.], in Collected abstracts of the Virginia Water Resources Conference, Richmond, Va., 1990, p. 57.

Woodside, M.D., and Rowan, M.E., 1991, Spatial distribution of selected trace metals in wetland sediments in the Chickahominy River.basin, Virginia [abs.]: Wetland Biogeochemistry Symposium, Baton Rouge, La.,: Laboratory for Wetland Soils and Sediments, Center for Wetland Resources, Louisiana State University, 1991, 1 p. 


\section{Index By Author}

A

Abe, J.M., 6, 8

Abram, E.C. 13

Ahlin, R.J. 7, 17

Anderson, D.G. 3, 11

Anderson, G.S. 10

Appel, C.A. 5

Augenstein, T.W. 16

B

Bachman, L.J. 10, 16

Back, William 2

Backman, L.J. 17

Bain, G.L. 11

Barnes, C.R. 9

Belval, D.L. 15

Bennett, R.R. 5

Blanchard, S.F. 7

Bogart, D.B. 3

Bower, R.F. 8

Bredehoeft, J.D. 5

Brown, D.L. 2, 11, 16

Brown, G.A. 7, 11

Brown, P.M., 2

C

Camp, J.D. 11

Carpenter, D.H. 5

Carrington, N.R. 7, 12

Carter, Virginia 7

Cederstrom, D.J. 3, 11

Chin, E.H. 3

Clark, C.P. 7

Clarke, P.F. 5

Cockey, E.J. 9

Cosner, O.J. 6, 11

Coupe, R.H., Jr. 7

Curwick, P.B. 6

Cushing, E.M. 2, 3

D

Daniels, W.V. 7

Davis, R.W. 6

DeBuchanne, G.D. 12

Denver, J.M. 16, 17

Dise, N.B. 6

Dodd, Kurt 5

Doyle, W.H. 6

Durfor, C.N. 3

E

Easton, F.J. 15

F

Farrington, S.T. 7

Ferguson, G.E. 5
Fisher, D.W. 3

Flynn, K.M. 6

Focazio, M.J. 16

Friz, T.O. 5

Froelich, A.J. 7, 8, 9, 13

Fuller, H.K. 5

G

Gambell, A.W. 3

Giusti, E.V. 2

Grover, N.C. 3

Guy, H.P. 3

$\mathrm{H}$

Hagan, G.F. 9

Hamilton, P.A. 3, 6, 8, 10, 16,17

Harlow, G.E., Jr. 8, 17

Harsh, J.F. 2, 4, 8

Hayes, D.C. 4

Hendrick, W.E. 8

Hirsch, R.M. 4, 8

Hom, P.J. 16

Hopkins, H.T. 4, 6, 10

Horwich, E. 11

Hufschmidt, P.W. 8, 10, 17

Humphrey, C.G. 10

Hyatt, G.J. 9, 12

I

Imhoff, E.A. 5

$\mathrm{J}$

Johnston, P.M. 4, 5

Johnston, R.H. 7, 8

$\mathrm{K}$

Kantrowitz, I.H. 2

Kapinos, F.P. 11

Knobel, L.L. 4, 8

Kull, T.K. 4, 6

L

Laczniak, R.J. 2, 6, 9, 10, 13,16

LaFevers, J.R. 5

Langer, W.H. 7, 13

Larson, J.D. 4, 6, 8, 9, 10, 13,17

Leahy, P.P. 4

Leavy, B.D. 13

LeCain, G.D. 8

Lescinsky, J.B. 9

Lewis, T.A. 9

Lichtler, W.F. 9
Lloyd, O.B., Jr., 6

Lohr, E.W. 4

Love, S.K. 4

Lynch, D.D. 6, 13

M

Mack, F.K. 5

McGreevy, L.J. 9

Meisler, Harold 4, 9

Meng, A.A., III 2, 4, 6

Miller, E.A. 11

Miller, E.M. 6, 11, 12

Miller, J.A. 2

Mohler, E.H., Jr. 9

Morsches, S.A. 13

Mulheren, M.P. 10

$\mathrm{N}$

Nelms, D.L. 6, 7, 17

Novak, C.E. 9

Nuckels, E.H. 4, 10, 12, 13

$P$

Papadopulos, S.S. 5

Patterson, J.L. 2

Paulhus, J.L.H. 2

Phelan, D.J. 12

Phillips, P.J. 10, 17

Pluhowski, E.J. 2

Posner, Alex 13

Powell, J.D. 4, 6, 7, 10, 17

Prugh, B.J., Jr. 4, 10, 15

Puckett, L.J. 4

R

Rapp, D.H. 12

Reid, M.S. 2

Richardson, D.L. 6, 10, 16,17

Riggs, H.C. 3

Rogers, S.M. 7, 10

Rowan, M.E. 18

Runner, G.S. 3, 12

$\mathrm{S}$

Sanford, Samuel 4

Schneider, W.J. 12

Scott, A.G. 4, 7, 10

Scott, W.B. 4

Shedlock, R.J. 10, 16, 17

Silvey,W.D. 2

Sinnott, Allen 3

Soule, P.L. 10

Speiran, G.K. 10, 18

Swain, F.M. 2
$\mathrm{T}$

Taylor, K.R. 2

Terry, J.E., Jr. 16

Terziotti, Sylvia 16

Tice, R.H. 12

Trainer, F.W. 4

Trescott, P.C. 5

U

U.S. Geological Survey 4, 5

V

Van Driel, J.N. 8

Vice, R.B. 5

W

Wait, R.L. 9

Walker, P.N. 9, 12

Watkins, F.A., Jr. 4

Williams, G.P. 3

Woodside, M.D. 9,18

Woodward, J.C. 7

Wright, W.G. 7, 17

Wyant, Timothy 4

Z

Zenone, Chester 13 